\title{
Squamous Cell Carcinoma Arising from Linear Porokeratosis - a case report and review of the literature
}

\author{
Snežana RADOŠ ${ }^{1}$, Milena MILOVANOVIĆ², Milica RAJOVIĆ ${ }^{3}$, Kristina KOSTIĆ4, \\ Ivana TUFEGDŽIĆ ${ }^{5}$, Lidija KANDOLF SEKULOVIĆ 4 \\ ${ }^{1}$ City Institute for Skin and Venereal Diseases, Belgrade \\ ${ }^{2}$ Institute for Student Health Care, Belgrade \\ ${ }^{3}$ Deparment of Plastic and Reconstructive Surgery, Military Medical Academy, Belgrade \\ ${ }^{4}$ Department of Dermatology, School of Medicine, Military Medical Academy, Belgrade \\ ${ }^{5}$ Institute of Pathology and Forensic Medicine, School of Medicine, Military Medical Academy, Belgrade \\ *Correspondence: Snežana Radoš, City Institute for Skin and Venereal Diseases, \\ Džordža Vašingtona 17, Belgrade 11000, Serbia, E-mail: snezana.rados@gmail.com
}

UDC 616.5-003.87

\begin{abstract}
Porokeratosis belongs to a group of disorders of keratinization that are characterized by the histopathological feature of the cornoid lamella, a column of tightly fitted parakeratotic cells. The etiology of porokeratosis is still unclear. Different variants of porokeratosis (PK) have been subsequently recognized, each with its own specific properties in terms of morphology, distribution and clinical course. Linear porokeratosis is one of the variants of porokeratosis, a rare disorder of keratinization that may develop into several epidermal malignancies, squamous cell carcinoma being the most frequent among all of them. Thus, a clinical surveillance for malignancy is an imperative. We present a case of a 54-year-old man with non-healing ulcer of the lower leg caused by squamous cell carcinoma arising on long-standing linear porokeratosis. The treatment included wide excision of tumor with the reconstruction of the area. Acitretin was prescribed for linear porokeratosis treatment. The follow-up of our patient so far has shown that he does not have new malignant lesions after surgical excision.
\end{abstract}

Key words: Carcinoma, Squamous Cell; Porokeratosis; Skin Neoplasms; Leg Dermatoses; Genes, p53; Dermatologic Surgical Procedures; Case Reports

\section{Introduction}

Porokeratosis (PK) belongs to a group of disorders of keratinization that are characterized by the histopathological feature of the cornoid lamella, a column of tightly fitted parakeratotic cells. The etiology of porokeratosis is still unclear. Variants of PK include: linear porokeratosis (LP), disseminated superficial porokeratosis (DSP) disseminated superficial actinic porokeratosis (DSAP), classic porokeratosis of Mibelli (MB), punctate porokeratosis (PP) and porokeratosis plantaris et palmaris disseminata (PPPD) (1). Linear PK is a rare form of porokeratosis that usually presents unilaterally with grouped characteristic lesions following the lines of Blaschko. Although progression to malignancy is rare, it can occur in all types of PK; linear PK is the most common subtype susceptible to malignant degeneration. The diagnosis of PK is typically based on the clinical examination as well as the histopathology analysis (2). A review of cases and case series found in the literature (3) shows that linear PK has approximately $19 \%$ chance of malignant transformation compared to approximately $7 \%$ to $11 \%$ chance (4) in other types of PK. The most common malignancy is squamous cell carcinoma (SCC) (in situ and invasive), followed by basal cell carcinoma (BCC) (2). The exact mechanism by which malignant degeneration develops in $\mathrm{PK}$ is not yet completely understood, but the experimental research has suggested that the tumor suppressor gene p53 has a role in the pathogenesis of all types of $\operatorname{PK}(5,6)$. 


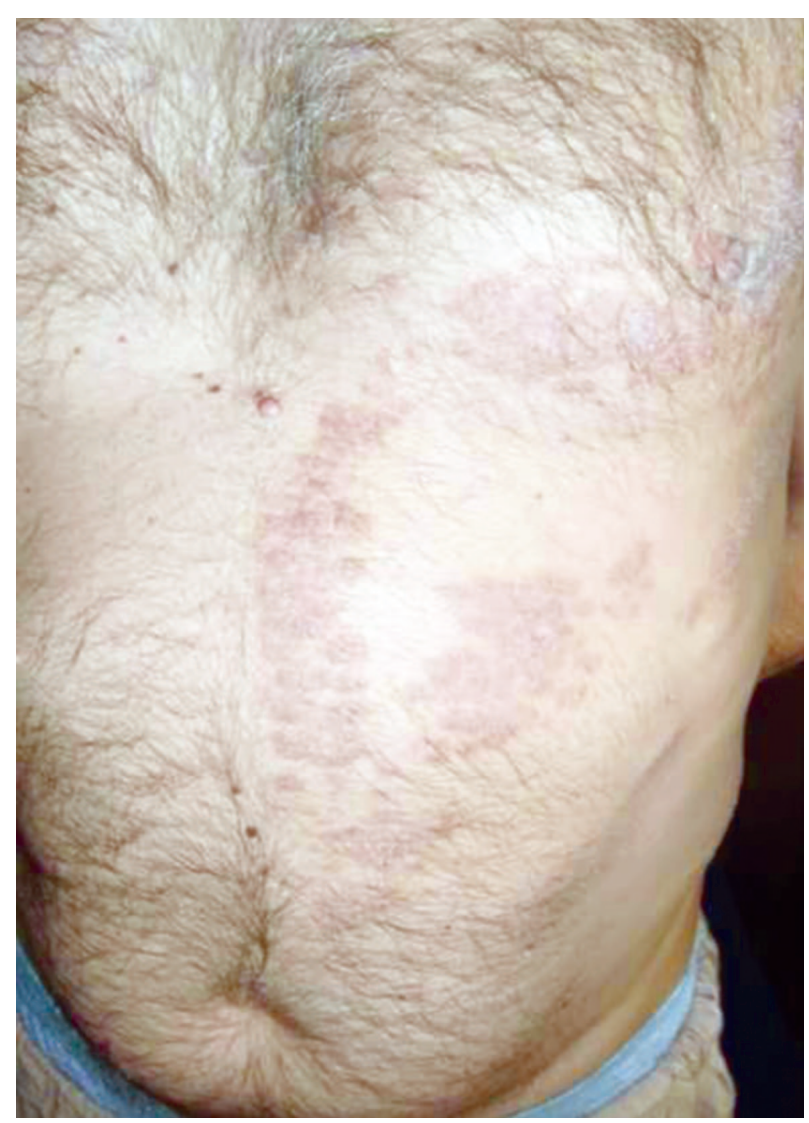

Figure 1. Linear porokeratotic plaques on the left side of the body

\section{Case Report}

A 54-year-old man was admitted to our Clinic with painful, non-healing and progressively worsening ulcer on the back side of his lower left leg. It appeared 6 months prior to admission at the site of lesional skin of porokeratosis. He was diagnosed with porokeratosis in his early childhood based on the clinical presentation, without biopsy and histopathological confirmation. He was not regularly followed up by a dermatologist since his condition did not cause any concern. However, six months after gradual development of ulceration he consulted a dermatologist. He was otherwise healthy and there were no chronic skin disorders and skin cancers in his family.

The physical examination of the skin revealed rough, confluent, hyperkeratotic plaques grouped and linearly arranged along the Blaschko lines on the left anterior side of the trunk, anterior and inner side of the left leg and dorsal

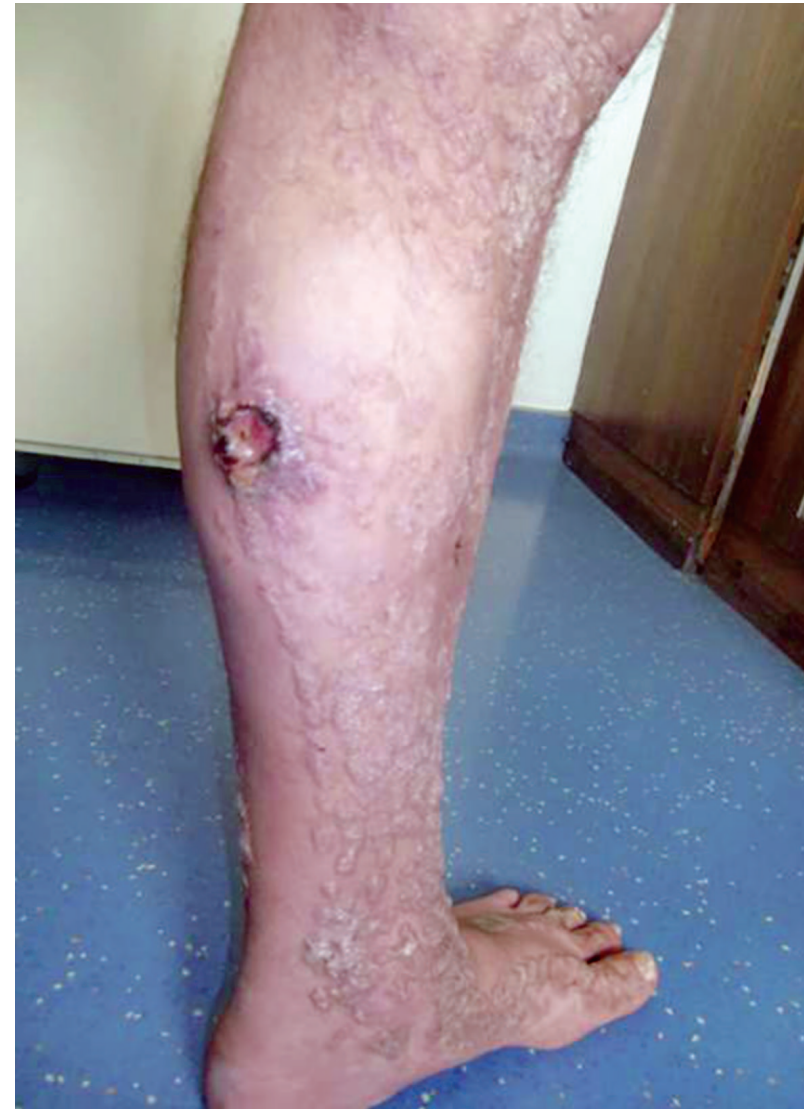

Figure 2. Round-shaped, solitary, well-demarcated ulcer on the posterior side of the lower left leg

part of the left foot (Figure 1). In addition, a round-shaped, solitary, well-demarcated ulcer, $7 \mathrm{~cm}$ in diameter, was present on the posterior side of the lower left leg (Figure 2).

A skin-biopsy of the lesions clinically resembling porokeratosis was indicated as well as the wide excision of the ulcerated tumor to be performed by a plastic surgeon. The histopathological analysis of skin biopsy confirmed porokeratosis based on the presence of cornoid lamella, which correlated to the raised hyperkeratotic border and was observed at the periphery of the lesion (Figure 3 ).

Histopathology analysis was performed on excised ulcer as well which showed irregular tumor nests that lead to diagnosis of squamous cell carcinoma, gradus II (Figure 4).

Complete and differential blood cell count, sedimentation rate, glucose, urea, serum creatinine, total proteins, albumins, uric acid, total bilirubin, electrolytes, iron, liver enzymes and C-reactive protein were within 
physiological limits. X-ray of the chest was performed alongside with ultrasound of the abdomen, pelvis and groins. According to the latest staging manual of the American Joint Committee on Cancer (7) our patient's disease was denominated stage II (T3NOM0). The patient had an uneventful post-excisional recovery with the complete healing of the surgical wounds and successful cosmetic result. Acitretin capsules, $25 \mathrm{mg}$ per day were also prescribed. So far no recurrence has occurred after 2-year follow-up consisting of skin checkup and regular ultrasound surveillance.

\section{Discussion}

Porokeratosis (PK) is a group of disorders of keratinization that usually present early in life as well-defined hyperpigmented macules or patches with a distinctive, typically raised, ridge-like hyperkeratotic border histologically characterized by a cornoid lamella. Linear porokeratosis (LP) is a rare form of porokeratosis that usually presents unilaterally with grouped lesions following the lines of Blaschko. Other variants of PK include disseminated superficial actinic porokeratosis - DSAP (the most common type, with the predominance of women in their third to fourth decade of life and involving sun-exposed areas such as the arms, legs, shoulders, and back; it spares the palms and soles); classic porokeratosis of Mibelli - MB (the second most common type, presenting typically in young boys with a large lesion on an extremity and associated with immunosuppression); punctate porokeratosis - PP and porokeratosis plantaris et palmaris disseminata - PPPD (less common type and presenting on the palms and soles) (2). A simultaneous presentation of several types of PK can occur but is seldom reported (4). Although progression to malignancy is rare, it can occur in all types of PK (2). Linear PK is the most common subtype susceptible to malignant degeneration, as is the case with our patient.

The diagnosis of all types of porokeratosis is typically based on the clinical examination. The presence of a flat, discolored, discrete lesion with a well-defined, elevated border suggests this disorder. Histologically, PK is characterized by a column of tightly fitted parakeratotic cells with pyknotic basophilic nuclei (8). This histologic feature (cornoid la-

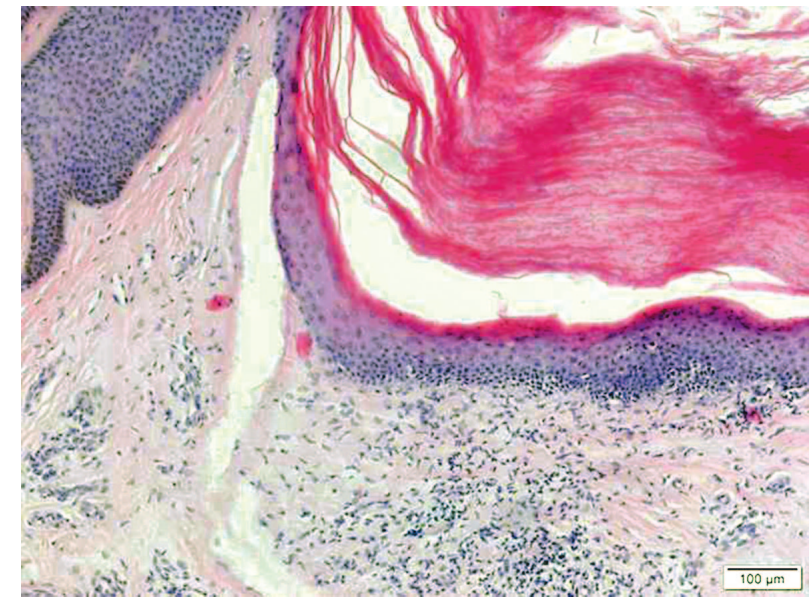

Figure 3. Tightly fitted parakeratotic cells which are well-circumscribed from the rest of the corneocytes extending through stratum corneum cornoid lamella (hematoxylin and eosin x 100)

mella), which correlates to the raised hyperkeratotic border, is observed at the periphery of the lesion. In our patient, the diagnosis was based on clinical manifestation and typical histopathological features.

A review of cases and case series found in the literature (3) shows that linear PK has approximately $19 \%$ chance of malignant transformation compared to approximately $7 \%$ to $11 \%$ chance (4) in other types of PK. The most common malignancy is squamous cell carcinoma (SCC) (in situ and invasive), followed by basal cell carcinoma (BCC) (2). The exact mechanism by which malignant

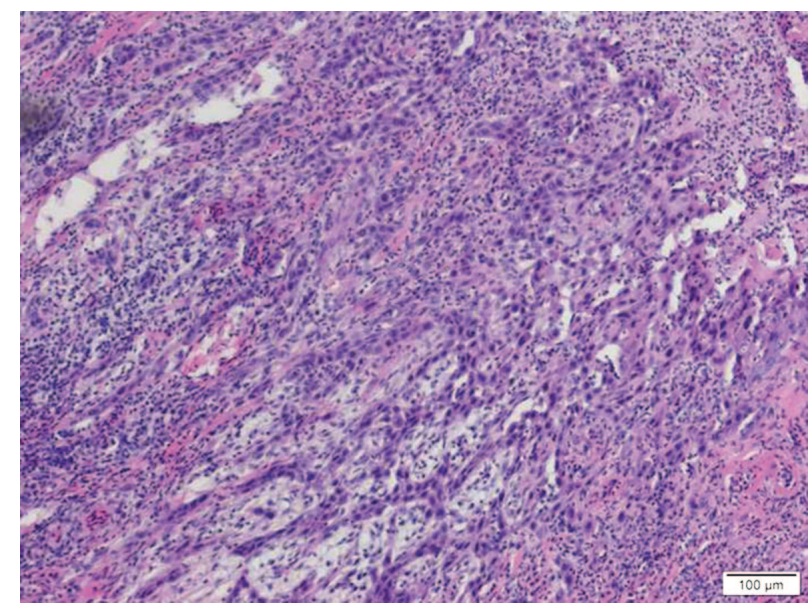

Figure 4. Irregular tumor nests (hematoxylin and eosin $x$ 100) 
degeneration develops in PK is not yet completely understood, the experimental research has suggested that the tumor suppressor gene p53 has a role in the pathogenesis of all types of PK because an over-expression of this gene has been demonstrated in these conditions through immunohistochemical studies using immunoperoxidase-stained antibody directed against the p53 protein $(5,6)$. Malignancy can occur after p53 gene inactivation resulting from the mutation and/or a loss of function.

Unrepaired ultraviolet (UV)-induced DNA lesions are directly responsible for p53 mutations in human BCCs and SCCs in a case review (9). However, PK-derived malignant lesions seem to have an increased occurrence in nonexposed skin, correlating with the results of a study in which no relation was found between UV exposure and the increased expression pattern of p53. Despite this, one of the consistently described risk factors for malignancy in $\mathrm{PK}$ is sun exposure. Other predisposing factors include exposure to ionizing radiation, the presence of extensive lesions, long duration of the lesion, and immunosuppression (9).

Similar to cutaneous SCC unrelated to PK, the majority of SCCs developing within the lesions of PK are successfully treated with local therapy - a wide surgical excision. However, several cases of metastatic SCC arising in the setting of PK have been reported (10). Therefore, close monitoring of patients should be conducted so that potential recurrent malignancies could be treated on time (9). In our case, the regular follow-up of our patient has shown that the wide surgical excision proved to be the first line of treatment.

As lymph node involvement by cSCC increases the risk of recurrence and mortality, a lymph node ultrasound is highly recommended. Sentinel lymph node biopsy (SLNB) has been used in the patients with CSCC, but there is no conclusive evidence of its prognostic or therapeutic value. There is no standardized follow-up schedule for the patients with cSCC. A close follow-up plan is recommended based on risk assessment of locoregional recurrences, metastatic spread or development of new lesions (11).

The eighth edition of the staging manual of the American Joint Committee on Cancer from 2017 incorporates important changes in the classification of skin cancers. Staging for squamous cell carcinoma considers head and neck tumors (excluding the eyelid) and does not offer solutions for other sites except the vulva, penis, and perianal region (7). Therefore, when staging our patient we used the previous, seventh edition which puts his disease in T3N0MO category.

In conclusion, linear PK presents an increased oncogenic potential. Its characteristic cornoid lamella appears to occur from a mutant group of abnormal keratinocytes, and the frequency of p53 mutations increases with the severity of the atypia. Linear PK is diagnosed clinically, but due to the characteristic features of the lesions histology is also used to confirm the diagnosis. Linear PK should be considered a pre-malignant condition that requires continuous observation for early detection of malignant transformation in order to avoid the progression of malignancy or the development of metastatic disease.

\section{Abbreviations}

PK - Porokeratosis

LP - linear porokeratosis

DSP - disseminated superficial porokeratosis

DSAP - disseminated superficial actinic porokeratosis

MB- classic porokeratosis of Mibelli

PP - punctate porokeratosis

PPPD - porokeratosis plantaris et palmaris disseminata

SCC - squamous cell carcinoma

BCC - basal cell carcinoma

UV - ultraviolet

SLNB - Sentinel lymph node biopsy

\section{References}

1. Sertznig P, von Felbert V, Megahed M. Porokeratosis: present concepts. J Eur Acad Dermatol Venereol. 2012;26(4):404-12.

2. Vivas AC, Maderal AD, Kirsner RS. Giant ulcerating squamous cell carcinoma arising from linear porokeratosis: a case study. Ostomy Wound Manage. 2012;58(11):18-20.

3. Curnow P, Foley P, Baker C. Multiple squamous cell carcinomas complicating linear porokeratosis. Australas J Dermatol. 2003;44(2):136-9.

4. Koley S, Sarkar J, Choudhary S, Dhara S, Choudhury $M$, Bhattacharya S. Different morphological variants of hypertrophic porokeratosis and disseminated le- 
sions of porokeratosis of Mibelli: a rare co-existence. Indian J Dermatol Venereol Leprol. 2011;77(2):199-202.

5. Nelson C, Cowper S, Morgan M. p53, mdm-2, and p21 waf-1 in the porokeratoses. Am J Dermatopathol. 1999;21(5):420-5.

6. Magee JW, McCalmont TH, LeBoit PE. Overexpression of p53 tumor suppressor protein in porokeratosis. Arch Dermatol. 1994;130(2):187-90.

7. Cañueto J, Román-Curto $C$. Novel additions to the AJCC's new staging systems for skin cancer. Actas Dermosifiliogr. 2017;108(9):818-26.

8. Wade TR, Ackerman AB. Cornoid lamellation. A histologic reaction pattern. Am J Dermatopathol. 1980;2(1):5-15.
9. Arranz-Salas I, Sanz-Trelles A, Ojeda DB. p53 alterations in porokeratosis. J Cutan Pathol. 2003;30(7):455-8.

10. Rongioletti F, Rebora A. Disseminated porokeratosis with fatal metastatic squamous cell carcinoma: an additional case of malignant disseminated porokeratosis. Am J Dermatopathol. 2002;24(2):144-8.

11. Stratigos A, Garbe C, Lebbe C, Malvehy J, del Marmol $\mathrm{V}$, Pehamberger $\mathrm{H}$, et al. Diagnosis and treatment of invasive squamous cell carcinoma of the skin: European consensus-based interdisciplinary guideline. Eur J Cancer. 2015;51(14):1989-2007.

\section{Skvamocelularni karcinom nastao od linearne porokeratoze}

\section{Sažetak}

Porokeratoza predstavlja poremećaj keratinizacije epiderma za koji su histopatološki karakteristične kornoidne lamele, kao i kolumne tesno poređanih parakeratotičnih ćelija. Etiologija porokeratoze još uvek je nejasna. Opisani su različiti oblici porokeratoze, svaki sa svojom specifičnim svojstvima u smislu morfologije, distribucije i kliničkog toka. Jedan od oblika porokeratoze je linearna porokeratoza, redak poremećaj keratinizacije koja se može razviti u nekoliko vrsta maligniteta epiderma, a najčešći od njih je skvamocelularni karcinom. Prikaz slučaja. U radu je opisan slučaj 54-godišnjeg muškarca sa bezbolnom ulceracijom na levoj potkolenici uzrokovanom skvamocelularnim karcinomom nastalim na te- renu dugogodišnje linearne porokeratoze. Lečenje je uključivalo široku eksciziju tumora sa rekonstrukcijom zahvaćenog regiona. Takođe, propisan je acitretin za terapiju porokeratoze. Dosadašnjim praćenjem našeg pacijenta nije pokazan nastanak novih malignih lezija nakon hirurške ekscizije. Zaključak. Uzevši u obzir da linearna porokeratoza pokazuje onkogeni potencijal i da se u velikom broju slučajeva može razviti neki od oblika maligniteta, najčešće skvamocelularni karcinom, redovno detaljno praćenje pacijenata radi ranog otkrivanja maligne transformacije, a samim tim i spečavanje dalje progresije bolesti, jeste imperativ.

Ključne reči: Skvamocelularni karcinom kože; Porokeratoza; Kožne neoplazme; Dermatoze nogu; Geni, p53; Dermatološke hirurške metode; Prikazi slučajeva 